\title{
Evaluataion of the Phytochemical and Antimicrobial Properties of Ethyl acetate Leaf Extract of Palicourea croceiodes
}

\author{
Udegbunam, I.S. ${ }^{1 *}$, V.I.E.,Ajiwe ${ }^{2}$, Wunuji, Hikon ${ }^{1}$ \\ ${ }^{1}$ Department of Chemical Sciences, Federal University, Wukari, Taraba, Nigeria \\ ${ }^{2}$ Department of Pure and Industrial Chemistry, NnamdiAzikiwe University, Awka, Nigeria
}

*Corresponding Author: Udegbunam, I.S., Department of Chemical Sciences, Federal University, Wukari, Taraba, Nigeria

\begin{abstract}
The leaf of Palicourea croceiodes (Rubiaceae) was extracted with ethyl acetate using cold maceration method, and the extract was subjected to preliminary phytochemical screening using standard methods and antimicrobial assay against some pathogenic bacteria and fungi including Staphylococcus aureus, Pseudomonas aeruginosa, Klebsiella pneumonia, Klebsiella aerogenes, E.coli, Proteus mirabilis, Enterobacter aerogenes, Candida albican and Aspergillusniger. Using the agar well diffusion method. The phytochemical screening revealed the presence of terpenes, acidic compounds, saponins, flavonoids and glycosides. The extract was also found to exhibit selective activities against some of the organisms with Minimum Inhibitory Concentration (MIC) of between $0.25 \mathrm{mg} / \mathrm{ml}$ and $0.0625 \mathrm{mg}$ and a Minimum Fungicidal Concentration of (MFC) of $0.125 \mathrm{mg} / \mathrm{ml}$ and $0.0625 \mathrm{mg} / \mathrm{ml}$. The study justified the use of the plant as an antibiotic in ethno-medical applications.
\end{abstract}

Keywords: phytochemical, Palicourea croceiodes, ethyl acetate, anti-microbial, ethno-medical.

\section{INTRODUCTION}

Traditional uses of herbal medicines have recently attracted the attention of the pharmaceutical and the scientific world which have been carrying out extensive research in the isolation and identification of natural products from plants and other organisms and their great use as medicines. Medicinal plants have become important elements in indigenous medicinal systems (Heinrich et al., 2001), and these plants contain various secondary metabolites which can be used against many diseases in the world today. Many plants also have been shown by studies as sources of various nutrients and non-nutrient molecules. These medicinal plants are known to produce certain bioactive molecules which are responsible for their antimicrobial properties (Rios and Recio, 2005., Sonibare et al., 2009., Kuete, 2010). A lot of them are responsible for plant flavours (e.g. the terpenoid capsaicin from chilli peppers) while others give plants their characteristic odour. Yet, others are responsible for the kind of pigments seen in plants (Cowan, 1999).

Currently, plants are still being employed by numerous developing countries as sources of therapeutic agents because they accept that medicinal plants are readily obtainable, reachable, inexpensive, and potent and with relatively lower occurrences of antagonistic reactions compared to modern conventional drugs (Adomi, 2008). In addition to their medicinal uses, herbs are of great importance in the maintenance of general health and well-being. They are valuable sources of vitamins, minerals and other nutrients. Some are delicious to taste, example mint and betelwhile others are not, and still, they are full of beneficial properties in their diverse ways. Juices are often consumed for their perceived health benefits for example; orange juice is rich in vitamin $\mathrm{C}$, folic acid and potassium. It is an excellent source of bioavailable antioxidant phytochemicals (Pascal et al., 2006).

According to the world Health Organization (WHO, 2001), 75\% of people still depend on plantcentered traditional medicine for primary health care globally. It seems likely that up to $80 \%$ of the world's populace rely primarily on so-called "traditional" medicine for primary health care; in many developing countries, the mainstream of the population depend on traditional therapies. This is to some extent due to poverty; but also because traditional systems are more culturally conventional and are able to meet psychological needs in a way western medicine does not (Prescott-Allen and Prescott-Allen, 1982). 
The research is carried out to justify the claim by traditional medicine practitioners for the use of Palicourea croceidesto cure various ailments such as urinary tract infections, vaginal infections which cause infertility in women, sexually transmitted diseases and other related ailments, The quest for search of activities of various antimicrobial agents on the plant is another justification for this research.

The aim of this study is identify the bioactive compounds from the ethyl acetate leaf extract of Palicourea croceiodes which may be used in the development of modern drugs. The outcome of this research may lead to the discovery and development of new compounds that are useful against diseases whose cures are not yet available.

Palicourea is a plant genus in the family of Rubiaceae. It contains about 200 species which range in habit from shrubs to small trees and is distributed throughout the new world tropics (Taylor, 2008).

The genus is not well studied. Most species are distylous, although a few on isolated Carribbean Islands seem to have lost the trait. Flowers are in racemes, having no scent and are normally pollinated by humming birds. Blue-black berries follow, and are thought to be distributed by birds. (Taylor, 2008).

\section{MATERIALS AND MethodS}

\subsection{Collection of Samples}

The plant materials were collected in December 2014, from Urum, Awka North Local Government Area of Anambra State and was identified and authenticated in the Biological Sciences Department of Federal University Wukari, Taraba State, Nigeria.

\subsection{Extraction of Plant Materials}

Leaves of the plant materials were reduced in size in order to promote drying. The plant parts were carefully dried at room temperature in order to prevent loss of active constituents which may be thermolabile. Electric grinder, mortar and pestle were finally employed to reduce the size of the dried plant materials to powder. . About $500 \mathrm{~g}$ of the material was extracted using 1 litre of ethyl acetate using the cold maceration method, the homogenous solution was filtered using what man No. 1 filter paper. The solvent evaporated with rotatory evaporator at $40^{\circ} \mathrm{C}$. The percentage yield of the extract was calculated and the concentrated extract was stored in a refrigerator for further analysis.

The extracts were dried after extraction and the percentage yield were calculated as:

$$
\text { PercentageYield }(\%)=\frac{\text { Extractweight }(g)}{\text { PlantSampleweight }(g)} \times 100 \%
$$

\subsection{Preliminary Phytochemical Screening of the Extract}

The ethyl acetate extract was screened for the presence of secondary metabolites using standard methods, (Silva et al., 1998).

\subsection{Sensitivity Test of the Leaf Extracts of Palicourea croceides}

The agar well diffusion method was used (Nostro et al., 2002). Ethyl acetate leaf extract of Palicourea croceiodes were diluted with Dimethyl Sulphoxide (DMSO). Bacteria from 24 hours slants were suspended in saline solution $(0.9 \% \mathrm{w} / \mathrm{v} \mathrm{Nacl})$ individually till the turbidity matches with that of McFarland 0.5 solution (mixture of $9.9 \mathrm{ml}$ of $1 \% \mathrm{w} / \mathrm{v}$ solution of $\mathrm{BaCl}_{2}$ ).

The standardized innocula of the isolates were uniformly streaked unto freshly prepared Mueller Hinton Agar plates with the aid of a sterile swab stick. The prepared plates were allowed to dry by keeping them half open and face downwards for 30minutes. With the aid of sterile cork borer $(6 \mathrm{~mm}$ in diameter), four appropriately labeled wells were punched into each agar, $0.05 \mathrm{ml}$ of each extract was used. DMSO was used as negative control while Oxfloxacin and Augmentin were used as positive control. The plates were kept for 30minutes in the bench for the diffusion of the crude extracts to take place before incubation. After, these plates containing bacterial cultures were lifted gently and placed in the incubator at $37^{\circ} \mathrm{C}$ for $24 \mathrm{hrs}$. 
Evaluataion of the Phytochemical and Antimicrobial Properties of Ethyl acetate Leaf Extract of Palicourea croceiodes

After incubation, the plates were examined and the inhibition zones were measured in $\mathrm{mm}$ a ruler. The observed inhibition zones were recorded appropriately in $\mathrm{mm}$ for the various diameter zone of inhibition. (Bryant, 1972 and Cruckshank et al., 1975). Triplicate plates were prepared for each extract and controls.

While for the fungi, sabouraud dextrose agar was used and the incubation period was 48hours. Clotrimazole was used as positive control. The zones of inhibition of the antifungal activities were also determined

\subsection{Determination of Minimum Inhibitory Concentration}

The minimum inhibitory concentration of the extracts were determined using the tube dilution method as outlined by Onyeagba 2004.

\section{RESULTS AND DISCUSSION}

Table1. Result of Phytochemical Screening of Palicourea croceiodes leaf extract

\begin{tabular}{|l|l|}
\hline \multirow{2}{*}{ Phytochemical Constituents } & Results \\
\cline { 2 - 2 } & Leaf \\
\hline Alkaloid & - \\
\hline Glycosides & + \\
\hline Saponins & + \\
\hline Flavonoids & + \\
\hline Acidic compounds & + \\
\hline Steroids/Terpenes & + \\
\hline Tannins & - \\
\hline Reducing sugars & - \\
\hline Anthraquinones & - \\
\hline Extract yield percentage & $\mathbf{7 . 1 3 \%}$ \\
\hline
\end{tabular}

The result of the extract yield percentage and preliminary screening were presented in (table 1), Preliminary phytochemical screening of the leaf extract of Palicourea croceiodes revealed the presence of phytoconstituents including terpenes, acidic compounds, saponin, cardiac glycosides and reducing sugar. This result showed the plant has quite a number of chemical constituents which may be responsible for its pharmacological actions. The medicinal properties of these compounds have been reported (Gill, 1992 and Kubmarawa et al., 2007).

The extract yield yield percentage of the acetate leaf extract was gotten as 7.13\%. The amount and type of phyto-constituents or active components extracted from a plant material is mainly affected by the extraction procedure and nature of phytocompounds which vary from sample to sample. The percentage yields might be attributed to the availability of extractable components resulting from chemical composition of plants and the polarity of the compounds (Sultana et al., 2009). Amongst other factors, efficiency of the extracting solvent to dissolve endogenous compounds might also be very important (Sultana et al., 2009).

Table2. Results of the Antibacterial Activities of the Crude Extracts of Palicourea croceiodes

\begin{tabular}{|c|c|c|c|c|c|c|c|c|c|c|c|c|c|}
\hline & \multicolumn{13}{|c|}{ AVERAGE DIAMETER ZONE OF INHIBITION $(\mathrm{mm})$ ON TEST ORGANISMS } \\
\hline EXTRACT/SOLVENT & $\begin{array}{l}\text { Vol. } \\
\text { used } \\
\left(\mathrm{cm}^{3}\right)\end{array}$ & P.a & E.a & K.a & S.a & K.p & P.m & E.c & & & & & \\
\hline Ethyl Acetate (Leaf) & 0.05 & 28.00 & 10.00 & 16.00 & 26.00 & 20.00 & 0.00 & 24.00 & & & & & \\
\hline \begin{tabular}{|l|} 
Oxfloxacin $200 \mathrm{mg}$ \\
distilled water
\end{tabular} & +0.05 & 20.00 & 24.00 & 18.00 & 25.00 & 16.00 & 10.00 & 18.00 & & & & & \\
\hline $\begin{array}{l}\text { Augmentine } 625 \mathrm{mg} \\
\text { distilled water }\end{array}$ & +0.05 & 18.00 & 20.00 & 22.00 & 22.00 & 0.00 & 0.00 & 4.00 & & & & & \\
\hline Control & 0.05 & - & - & - & E & - & - & & 0.125 & 0.0313 & 0.125 & 50.0313 & 0.625 \\
\hline $\mathrm{MIC} \mathrm{mg} / \mathrm{ml}$ & & 0.0625 & 0.0625 & 0.125 & 0.0313 & 0.125 & 0.0313 & 0.0625 & 0.25 & 0.0625 & 0.25 & 0.0625 & 0.125 \\
\hline $\mathrm{MBC} \mathrm{mg} / \mathrm{ml}$ & & 0.125 & 0.25 & 0.25 & 0.0625 & 0.25 & 0.0625 & 0.125 & & & & & \\
\hline
\end{tabular}

$P . a=P$ seudomonas aeruginosa, E. $a=$ Enterobacter aerogenes, $K . a=$ Klebsiella aerogenes, S.a=Staphylococcus aureus, K.p=Klebsiella pneumonia, P.m=Proteus mirabilis, E.c=E.coli 
Evaluataion of the Phytochemical and Antimicrobial Properties of Ethyl acetate Leaf Extract of Palicourea croceiodes

Table3. Results of the Antifungal Activities of the ethyl acetate leaf extract

\begin{tabular}{|l|l|l|l|}
\hline & & \multicolumn{2}{|l|}{ DIAMETER ZONE OF INHIBITION(mm) } \\
\hline SAMPLE TESTED & VOLUME USED $\left.\mathbf{( c m}^{\mathbf{3}}\right)$ & Candida albican & Aspergillus niger \\
\hline Ethylacetate Leaf & 0.05 & 20 & 18 \\
\hline Clotrimazole $(100 \mathrm{mg})$ & 0.05 & 14 & 10 \\
\hline MBC mg/ml & & 0.0625 & 0.0313 \\
\hline MFC mg/ml & & 0.125 & 0.0625 \\
\hline
\end{tabular}

The leaf extract of Palicourea croceoides was investigated for their antibacterial and anti-fungal activities and the results are presented in table 2 and 3 . The sensitivity test on extract showed that Pseudomonas aeruginosa $(28.00 \mathrm{~mm})$, E.coli $(24.00 \mathrm{~mm})$ and Staphylococcus aureus $(26.00 \mathrm{~mm})$ were the most inhibited organisms and were higher than that of commercial antibiotics like Oxfloxacin and Augmentin. The high diameter zone of inhibition exhibited by these test organisms corroborated to a good antimicrobial agent and could be an alternative to the antibiotics in the treatment of infections they cause since most of them have developed resistance against the known antibiotics. (Singleton, 1999).The antifungal assay of the ethyl acetate leaf extract of Palicourea croceiodes showed different responses to the test organisms with activity reported for candida albican and Aspergillusniger with diameter zone of inhibition of $20 \mathrm{~mm}$ and $18 \mathrm{~mm}$ respectively. The level of antimicrobial activities exhibited by these extracts from the antibacterial and antifungal screening results with the test bacteria and fungi justified the traditional uses of the plant, and this pathogens cause infection and infertility problems. (Greenwood and Pentherer, 1992).

The result shown in Table 3 revealed that the extracts were sensitive on the fungi tested and is less compared with the bacterial counterpart (Table 2), this is because bacteria are more sensitive than fungi. The reason for this low susceptibility is probably their eukaryotic nature which is responsible for the advance cellular and molecular process when compared to bacteria which are prokaryotic in nature (Momohet.al., 2012).

The MIC was the lowest concentration of the extract that is required to inhibit visible growth of test organism and is recorded ranging from $0.25 \mathrm{mg} / \mathrm{ml}-0.0625 \mathrm{mg} / \mathrm{ml}$ for the test bacteria, for the fungi, the $\mathrm{MIC} / \mathrm{MBC}$ was reported in the range of $0.125-0.0625$. This indicates that the extract is effective even at low concentrations.

\section{CONCLUSION}

The results of the present study showed that ethyl acetate leaf extract of Palicourea croceiodesis composed of many bioactive compounds which have significant anti microbial activity and therefore suggest its potential to be used in the development of strong antibiotics and as an alternative therapeutic agent for inflammatory diseases and infertility problems. The research therefore justifies the use of this plant in traditional medicine.

\section{REFERENCES}

Adomi, P.O., (2008). Screening of the leaves of three Nigerian medicinal plants for antibacterial activity. African Journal of Biotechnology 7, 15:2540-2542.

Bryant, M.C., (1972). Antibiotics and their laboratory control, $2^{\text {nd }}$ edition, Buterworths, London p.85.

Cowan, M.M., (1999). Plants products as anti-microbial agents.Clinical Microbiology Reviews. 12:564-582.

Cruckshank, R., Dagaid, J. P., Morimion, B. P., Swain, R. H. A., (1975). Medical Microbiology Vol. 11\& $12^{\text {th }}$ edn. Churchill Living Stone, Edinburgh, London and New York pp. 194-203.

Gill, A. F., (1992). Economic Botany: A textbook of useful plants and plant products, $2^{\text {nd }}$ edition, McGraw Hill book Co. Incorporated U.S.A, pp 242-266.

Greenwood, D.S., Pentherer, C.B.,(1992). Medical Microbiology:A Guide to Microbial Infections, Pathogens, Immunity, Laboratory Diagonosis Control (14 ${ }^{\text {th }}$ edition). Churchill Livingstone Medical Division of Longman Group, Bungay, U.K. pp. 72-73.

Heinrich, M., Barnes, J., Gibbons S., Williamson, E.M., (2001). Fundamental of Pharmacognosy and Phytotherapy. Churchill Livingstone Press, Edinburgh.Pp15-18.

Kubmarawa ,D., Khan,M., Punah,E., Hassan,A. M.,(2007). Journal of Medicinal Plants Research, 2(12): 53525335.

Kuete, V., (2010). Potential of Cameroonian plants and derived products against microbial infections: A review. PlantaMedica, 76:1-13. 
Momoh, A.O., Oladunmoye, M.K., and Adebolu, T.T., (2012). Evaluation of the antimicrobial and phytochemical properties of oil from castor seeds (Ricinuscommunis Linn), Bulletin of Environmental Pharmacology and Life Sciences, 1(10): 21-27.

Nostro, A., Germano, M. P., Diangelo, V., Marino, A., Cannattelli, M. A. (2002). Application Microbiology, 30:379.

Onyeagba, R.A.(2004).Laboratory Guide for Microbiology First Edition, Crystal Publishers, 95-117.

Pascal, M.E., Carretero, M.E., Slowing, K.V., Villar, A.,(2006). Phytochemical investigation of Alteaofficinalis l. Natural Product Research, 124(14):1358-1364.

Prescott-Allen,R., and Prescott-Allen C.,(1982). What's Wildlife Worth? Economic Contributions of Wild Animals and Plants to Developing Countries London.Earthsacan.

Rios, J.L., and Recio, M.C., (2005). Medicinal plants and antimicrobial activity. Journal of Ethnopharmacology, 100:84-94.

Silva, G.L., Lee, I., and Douglas, K.A.,(1998).Special problems with extraction of plants. In: Cannel, J. P. R. (ed.). Natural Products Isolation. Humana Press Publishers, New Jersey, (USA). Pp. 356-358.

Singletton, P., (1999). Bacteria in Biology, Biotechnology and Medicine, $4^{\text {th }}$ edition, John Wiley and Sons Limited, New York.P.61.

Sonibare, M.A., Soladoye, M.O., Esan, O.O., Sonibare, O. O.,(2009). Phytochemical and antimicrobial studies on four species of Cola schott and endl.(Sterculiaceae).African Journal of Traditional Complementary and Alternative medicine. 6(4): 518-522.

Sultana, B., Anwar, F., Ashraf, M., (2009). Effect of extraction solvent/technique on the antioxidant activity of selected medicinal plant extracts. Molecules, 14, 2167-2180.

Taylor, Charlotte M. (2008) PalicoureaAubl. (Rubiaceae: Psychotrieae) Retrieved $28^{\text {th }}$ February, 2015

World Health Organization (2001).Legal Status of traditional medicines and complementary/alternative medicine: A world-wide review of World Health Organization, http://apps.who.int/medicine/ dous/en/d/ Jh2943e/. Retrieved $28^{\text {th }}$ February, 2015

World Health Organization.(WHO), (1976). African Traditional Medicine, Technical Report Series, NO.1. Brazzaville.

Citation: I. Udegbunam et al., "Evaluataion of the Phytochemical and Antimicrobial Properties of Ethyl acetate Leaf Extract of Palicourea croceiodes", International Journal of Advanced Research in Chemical Science (IJARCS), vol. 4, no. 7, pp. 11-15, 2017. http://dx.doi.org/10.20431/2349-0403.0407003

Copyright: (C) 2017 Authors. This is an open-access article distributed under the terms of the Creative Commons Attribution License, which permits unrestricted use, distribution, and reproduction in any medium, provided the original author and source are credited. 